\title{
INVESTIGATION OF URBAN GROWTH EFFECTS ON FOREST AREA BY CREATING DIFFERENT SIMULATION SCENARIOS
}

\author{
I. E. Ayazli ${ }^{1, *}$, S. Baslik ${ }^{2}$, A. E. Yakup ${ }^{1}$, F. Kilic Gul ${ }^{3}$, D. Kotay ${ }^{1}$, M. Gultekin ${ }^{4}$ \\ ${ }^{1}$ Department of Geomatics Engineering, Cumhuriyet University, 58140 Sivas, Turkey - eayazli@ cumhuriyet.edu.tr, \\ (emirykp@gmail.com, deryakotay047@gmail.com) \\ 2 Department of Informatics, Mimar Sinan Fine Arts University, Istanbul, Turkey - sbaslik@ gmail.com \\ ${ }^{3}$ Department of Geomatics Engineering, Y1ldız Technical University, 34220 Davutpaşa, Istanbul, Turkey - fkilic@ yildiz.edu.tr \\ ${ }^{4}$ Land Registry Cadastre II ${ }^{\text {nd }}$ Regional Directorate, Kartal-Maltepe-Adalar Cadastre Department, 34860 Kartal, Istanbul, Turkey - \\ mahmutgultekin@hotmail.com
}

\section{ICWG III/IV}

KEY WORDS: Simulation, Cadastre, GIS, Urban Growth

\begin{abstract}
:
It is necessary to keep urban growth under control according to the understanding of sustainable urban management in rapidly growing cities. In other words, sustainable urban management requires estimating how the land cover will change and in which direction the urbanization will be in the coming years, as well as knowing the current structures of the cities. Therefore, simulation models are frequently used for monitoring urban growth. The results of simulation models help to obtain background information that will be the basis for the formation of a "sustainable urban life" by allowing the determination of the natural areas that can face the threat of urbanization. The cadastral structure is one of the basic variables affecting the growth of a city. Therefore, the purpose of the study is to investigate urban growth by producing cadastral parcel-based simulation models. The land cover data required to create a simulation model were generated from cadastral maps and land registry data, in four different time periods. Within the scope of the study, cellular automata-based urban growth simulation models for the years 2030, 2050 and 2070 were produced, and the land cover changes that occurred in Sancaktepe were investigated.
\end{abstract}

\section{INTRODUCTION}

The United Nations (UN) has organized various meetings since 1987 and has proposed the sustainable development model to improve the quality of life in rapidly growing cities. As a part of the sustainable development model, urban growth is required to be kept under control according to the understanding of sustainable urban management. In other words, sustainable urban management requires estimating how the land cover will change and in which direction the urbanization will be in the coming years, as well as knowing the current structures of the cities (Ayazli et al. 2014).

Nowadays, natural resource destruction that may occur due to urban growth in city walls is caused by estimates based on pure observation, and natural conservation areas are determined. However, the studies that emerge as a result of these observations do not exactly reflect the real development dynamics as they are based on possible urban growth trends. Realistic urban growth predictions must have a scientific certainty, and predictions should be transferred to plans in a way to create a sustainable economy and a sustainable natural environment by taking into account the city's economic growth potential. Therefore, growth predictions are an indispensable tool in the identification of protected areas and in making sustainable urban development plans.

Property status is one of the main variables affecting the growth of a city. Urban growth should be discussed and explained with its own primary variables such as area, distance, land cover and property, in other words, it should be evaluated directly in its own specific context to directly understand the size, growth rate, time and direction, etc. dynamics of the physical space (Baslik 2008). Cities have been classified in two different ways as organically/naturally growing and planned/artificial growing cities from antique age until today (Batty and Longley 1994). In a sense, planning has been necessitated by urban growth and many urban growth models have been developed.

From the mid-20th century, the systems approach and prediction models began to be used in planning, and the theory of complex has been used for the modeling of the complex and dynamic structure of cities (Baslik 2008; Ayazli et al. 2015). The creating of the simulation models of cities can now be easily made thanks to developments in computer technology. Thus, simulation models are used in many studies for urban growth today (Clarke et al. 1997; Benenson and Torrens 2004; Batty 2007; Baslik 2008; Ayazli et al. 2015).

Cellular automata (CA) based simulation models are generally used to follow the changes caused by urban growth on the land cover (Clarke et al. 1997; Silva and Clarke 2002; Benenson and Torrens 2004; Jantz and Goetz 2005; Batty 2007; Baslik 2008; Akın et al. 2014; Ayazli et al. 2015). CA has five basic elements including space, state, neighborhood, transition rules and time (Benenson and Torrens 2004; Hammam et al. 2004). CA is an operating system which allows to divide a state into cells and to predict the future state of each cell according to the state of neighboring cells. In CA-based urban models, the state of a cell represents the land cover (Ayazli 2011). Information can be

\footnotetext{
* Corresponding author
} 
exchanged between the cells or dispersed towards the neighbors; in this sense, CA can support the spread of knowledge to space (Benenson and Torrens 2004; Ayazli 2011).

Data such as land cover, slope, transportation, plan decisions and constraints, administrative borders, lithology and structural features, socio-economic data, etc. are generally used in CAbased studies in which urban growth is monitored. In studies, although pixel sizes vary according to the purpose of the project, they vary between $10 \mathrm{~m}$ and $500 \mathrm{~m}$ (Silva and Clarke 2002; Jantz and Goetz 2005; Sevik 2006; Oguz et al. 2007; Baslik 2008; Ayazli et al. 2015).

The study area is Sancaktepe district of Istanbul which is a country's fast-growing district, is spread towards rural and forest areas and unavoidably affects the surrounding water sources. Sancaktepe district was established in 2008 with Law No.5747 on "Establishment of the District within the Borders of the Metropolitan Municipality and Amendments in Some Laws" that entered into force on March 6, 2008, and it was formed by combining Samandıra, Sarigazi and Yenidogan regions. According to the Address Based Population Registration System (ABPRS) data published by the Turkish Statistical Institute (TSI), a population increase of about 55\% occurred from 2008 to 2015 in the district (TSI 2016).

In this study, starting from the institution cadastre, five land covers data including settlement area, forest areas, agricultural area, formerly forested lands (2B lands) according to article 2 of the Forest Law, and open spaces were produced from cadastral maps in four different periods. In addition, three-period transportation and three-period building, one-period administrative borders (district, neighbourhood, and village) produced by Istanbul Metropolitan Municipality (IMM), twoperiod transportation, one-period building, and the Digital Elevation Model (DEM) produced by the General Command of Mapping (GCM) data were also used in the model. Three different urban growth simulation models (UGSM) for the years of 2030, 2050 and 2070 were created by processing the obtained data in a database, and short, medium and long-term changes in land cover were determined. According to the results found, the direction of urbanization in the study area is from west to east. In particular, the open spaces, agricultural areas and forests in the neighbourhoods located in the east of the district are expected to be transformed into settlement areas from the short term.

\section{STUDY AREA}

Significant natural and environmental areas have been under the threat of urbanization due to the land cover that changed as a result of rapid urbanization experienced in the district, a large part of which has been included within Omerli Watershed Protection Zone by Istanbul Water and Sewerage Administration (İSKİ). Rapid population growth and migration over the past years have brought along squatting, illegal housing, and uncontrolled urbanization and led to changes in the land cover of the district, and this situation has played an important role in the diversification of the property pattern. The geographical location, increasing population density and transportation potential of the district are important factors for the investigation of changes in property structure.

Sancaktepe district was established in 2008, it neighbors with Sultanbeyli, Cekmeköy, Kartal, Maltepe, Pendik, Atasehir and Umraniye districts, and has 19 neighborhoods (Figure 1). Its surface area is $62.41 \mathrm{~km} 2$, and its population increased from
229,093 to 354,882 during seven years from its establishment in 2008 until 2015 (TSI 2016).

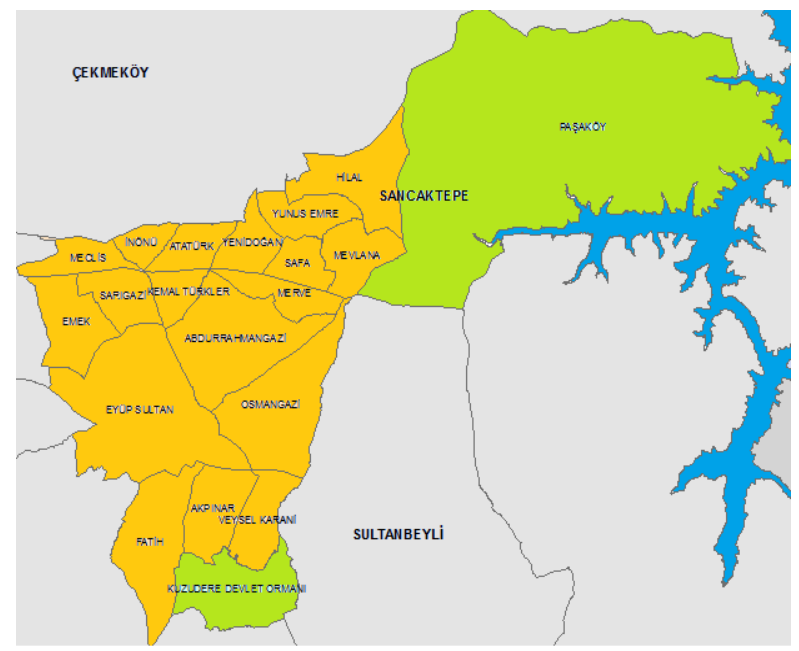

Figure 1. Administrative borders of Sancaktepe District

\section{METHODOLOGY}

\subsection{Model Background}

The cadastral maps obtained from Umraniye Cadastre Department and the zoning plans obtained from Sancaktepe Municipality need to be transferred to the urban growth database, which is a geographic database, for the preparation of settlement area, building stock, land cover and accessibility data used in the study. Therefore, the cadastral data, zoning plans and the data of the years during which zoning movements were intense in the region were firstly analyzed. Four different time zones appear when cadastral map production and the intensity of zoning activities are taken into account. The studies of the institution cadastre were initiated in 1956 in the project area, and a total of 33 cadastral maps were produced at different scales until 1962. 56 cadastral maps between 1988-1992 and a total of 82 cadastral maps between 1997-2002 were produced, and zoning mobility was also most intense in the region in this time period. Finally, the process that started with Law No. 5747, which entered into force on 06.03.2008, and has come until today constitutes the fourth period for Sancaktepe. In the last period, over 30 cadastral maps were produced, and the first zoning plan in which Sancaktepe was handled as a whole was made. Accordingly, the periods of the study were determined as 1961, 1992, 2001 and 2014. Thus, important events in the name of urban growth in the historical process were taken into account, and simulation models were also prepared for the future according to the current data.

The obtained data were stored in a database management system to perform the storage, organization, analysis and presentation of the data to be used in the creating of the simulation model in an easy way. Four sets of spatial data for the years agreed for the preparation, storage, processing and analysis of historical data based on space were created within the database. The Parcel class in which settlement area and land use data would be produced, the Road class in which accessibility data would be prepared, and the Building class in which building stock data would be stored were created within the data sets. 
There is a small number of CA-based software used in the prediction of urban growth. The main ones are Geonamica/Metronamica software developed by the Research Institute Knowledge Systems (RIKS), USGS and SLEUTH software developed at Santa Barbara Institute of California University, and DUEM (Dynamic Urban Evolutionary Modeling) software which was firstly developed by Yichun Xie and then by Michael Batty and Zhanli Sun (Ayazli et al. 2015). SLEUTH and DUEM software are academic software and free of charge. In DUEM software, land cover classes come with the program as defined and cannot be changed. Therefore, the software does not have a flexible structure. SLEUTH software, which is an open source and free software, was preferred to be used in the study as it is easier to use than the other two software.

As input data, it requires slope, two-period land cover, the excluded area, at least four periods urban areas, at least two periods transportation and hillshade. While the software creates the UGSM in the test, calibration and prediction phases, it uses four growth rules and five growth coefficients associated with these rules (Table 1) (SLEUTH 2016).

Growth Rules

Growth Coefficients

\begin{tabular}{ll}
\hline Spontaneous & Dispersion, Slope \\
New Spreading Centres & Breed, Slope \\
Edge Growth & Spread, Slope \\
$\begin{array}{l}\text { Road-Influenced } \\
\text { Growth }\end{array}$ & $\begin{array}{l}\text { Breed, Slope, Road Gravity, } \\
\text { Dispersion }\end{array}$ \\
\hline
\end{tabular}

Table 1. Growth rules and coefficients (Ayazli 2011)

The first phase is the Test phase while creating the simulation model. In the test phase, whether the data are prepared in the format desired by the software is checked for the calculations of the data to be used in the system. The data set can be used in the calibration phase if it has been produced in the desired standards (SLEUTH 2016).

The calibration phase is carried out in three steps within itself, and it is aimed to calculate the most suitable growth coefficient values for the estimation phase. The most suitable coefficient values are determined using the Brute Force Calibration (BFC) method according to 13 criteria calculated. Although there is not yet a consensus on which or which one of these criteria will be used to determine coefficient, it is recommended to determine the coefficients by the Optimum SLEUTH Metric (OSM) method in recent studies in the literature (Dietzel and Clarke 2007). Therefore, the Optimum SLEUTH Metric (OSM) method was used during the calibration phase in which the coefficients are calculated.

The OSM method is a method which was developed by Dietzel and Clarke (2007) and in which coefficients are determined using Compare, Pop, Edges, Clusters, Slope, X-Mean and YMean criteria, from the criteria calculated after each calibration (Dietzel and Clarke 2007). According to the OSM method, it is passed to the estimation stage where the UGSM will be produced for the future after calculating the coefficients, and
UGSM is created for the year for which the estimation will be made.

\subsection{Data Processing and Creating of UGSM}

The procedure steps followed in the study are shown in Figure 2 and were initiated by the archival studies carried out at Umraniye Cadastre Department. Over 70.000 parcel data from different years which were obtained as a result of the archival study were organized in the GIS environment, and input data were prepared to create UGSM. After UGSM had been created, change detection analysis was performed, the direction and effects of urban growth were examined, and the results obtained were studied.

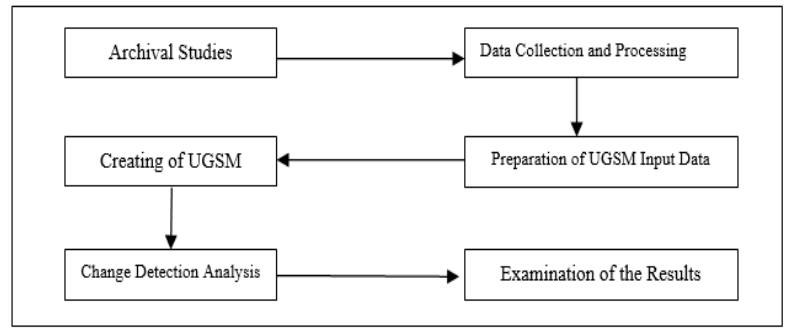

Figure 2. Workflow of creating UGSM

The first step of the study is the archival study carried out at Umraniye Cadaster Department to reveal the property pattern of Sancaktepe District. In these studies, parcel-based settlement area, land cover data and transportation data (Data for the years of 2006 and 2013 were obtained from IMM) were produced for the years of 1961, 1992, 2001 and 2014. In this way, the cadastral data of the past years that are not regularly recorded in our cadastral system have been recorded in the Urban Growth Database prepared.

The second phase, Data Collection and Processing phase was initiated after having completed archival studies. The suitability, zoning, accessibility, land cover, and socioeconomic data, which are the basic data needed by the UGSM, were produced in this phase.

The group classified as suitability data have spatial information about whether the land use function will be suitable for the settlement area in the future. The parcel-based settlement area data for the years of 1961, 1992, 2001 and 2014 produced from cadastral maps, and the slope data produced from DEM, obtained from GCM and having $10 \mathrm{~m}$ spatial resolution were used as suitability data in the project.

Building data produced from cadastral maps and obtained from IMM were overlapped with parcel data, and the weight of the parcels on which there were building and the weight of nonparcel data were set as 100 and 75, respectively, and they were included in four-period settlement area data.

The slope criterion can be adjusted while establishing the simulation model, and this value is defined as $21 \%$ in software. However, it was determined that urbanization activities took place even in places with a slope of over $40 \%$ in the region. In particular, it was determined that urbanization occurred in places where the slope was greater than $40 \%$ in the region 
including Mevlana, Safa and Yunus Emre quarters (Figure 3). Therefore, the slope criterion was set as $80 \%$ in the model.

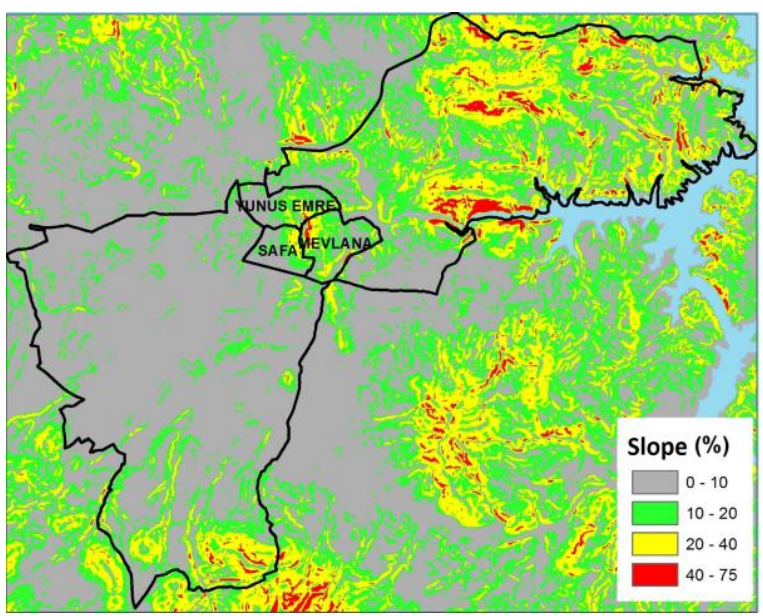

Figure 3. Quarters with a slope of greater than $40 \%$

In the 1: 100.000-scaled Environment Plan (EP) prepared for Istanbul, very small region within the boundaries of the district carries a geological risk, and this is a region that has already completed its urbanization. Therefore, the geological structure was not taken into account in the model created.

The zoning data group includes the data that are designed in plans, direct urban growth and impose some restrictions. It includes restrictions such as areas suggested for housing, proposed agricultural areas, superstructure facilities such as bridges, suggested roads etc., functions and protection areas. However, as it is seen in Figure 4, urbanization activities are available even in places with a slope of over $50 \%$ when the slope data included in the model is examined within the scope of the suitability data. Therefore, no zoning data that would impose a restriction to the model was used by considering the urbanization of Istanbul.

Highways, railways, etc. transportation data are included in the transportation/accessibility data class. The accessibility data for the first, second and third periods were produced by digitizing the cadastral maps of the relevant periods. However, it was determined that the roads opened were not processed in the maps because some cadastral maps were out of date in the second period, and the transportation data of the second period were produced using the satellite images and aerial photographs of the relevant period in the IMM City Guide. The transportation data for the years 2006 and 2013 were obtained from the IMM and the road data of the fourth and fifth periods were organized respectively. Five-period accessibility road data are weighted as in Table 3.

\begin{tabular}{ll} 
Road Type & Code \\
\hline Motorway, intercity road & 100 \\
Main street, boulevard, etc. & 75 \\
Motorway, intercity road & 50 \\
Village road & 25
\end{tabular}

Table 3. Road Types and Codes
3 separate datasets with $10 \mathrm{~m} \times 10 \mathrm{~m}, 20 \mathrm{~m} \times 20 \mathrm{~m}$ and $40 \mathrm{~m} \times 40 \mathrm{~m}$ pixel sizes were created in simulation models created using CAbased SLEUTH software. In these data sets, the slope, land cover, areas out of urbanization, settlement area, transportation and hillshade data were created according to the standards of the software (SLEUTH 2016; Ayazli 2011). Three UGSMs were created for the years 2030, 2050 and 2070 by making the necessary changes in the scenario files. The summary of the calibration results of the calculations made during the calibration phase is presented in Table 4 .

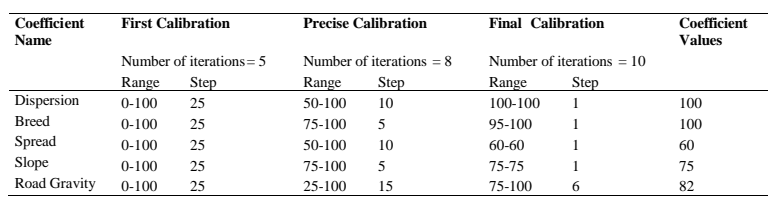

Table 4. Summary of calibration results

\section{RESULTS}

Rapid population growth and migration over the past years have brought along squatting, illegal housing, and uncontrolled urbanization and led to changes in the land cover of the district. According to the growth coefficients calculated for the land cover, three different UGSMs were created for the years of 2030, 2050 and 2070, and the change detection analyses were performed between 1961-2014, 2014-2030, 2014-2050 and 2014-2070. According to the results in Table 5, the ratio of settlement area which was $0.1 \%$ in 1961 increased to $10.9 \%$ in 2014. In addition, there is a decrease of about $10 \%$ in agricultural areas and $2 \%$ in forests within the study area. According to the UGSM results, this change is expected to continue in the short, medium and long term (Table 6).

\begin{tabular}{lrrrr} 
Land cover & \multicolumn{2}{c}{1961} & \multicolumn{2}{c}{2014} \\
& $\begin{array}{l}\text { Number } \\
\text { Pixels }\end{array}$ & $\begin{array}{c}\text { Ratio } \\
(\%)\end{array}$ & $\begin{array}{l}\text { Number } \\
\text { Pixels }\end{array}$ & $\begin{array}{l}\text { Ratio } \\
(\%)\end{array}$ \\
\hline Settlement Area & 2.290 & 0,1 & 192.320 & 10,9 \\
Agricultural areas & 287.009 & 16,3 & 108.869 & 6,2 \\
2B Lands & - & - & 8.777 & 0,5 \\
Forest Areas & 271.087 & 15,4 & 235.353 & 13,4 \\
Open spaces & 15.774 & 0,9 & 12.326 & 0,7 \\
\hline
\end{tabular}

Table 5. Land cover for the years 1961 and 2014

\begin{tabular}{lllll}
$\begin{array}{l}\text { Transformation into settlement } \\
\text { areas }\end{array}$ & \multicolumn{5}{c}{ Proportional Change } \\
\hline From agricultural areas & 47 & 23 & 70 & 83 \\
From 2B lands & $-2014(\%)$ & $2014-2030(\%)$ & $2014-2050(\%)$ & $2014-2070(\%)$ \\
From forests & 12 & 15 & 46 & 58 \\
From open spaces & 54 & 25 & 70 & 88 \\
\hline
\end{tabular}

Table 6. Land covers expected to be transformed into settlement area in the future

\section{DISCUSSION AND CONCLUSIONS}

The simulation model created using SLEUTH software running based on CA includes the land cover prediction of 2070. According to the simulation result, almost all agricultural lands and open spaces are expected to be transformed into built-up 
areas in the settlement areas in Sancaktepe. When transportation projects designed in our day and the urban spread structure of Istanbul are taken into account, areas located in Sancaktepe District that are not yet built-up such as Pasakoy and its surroundings are thought to be under an intense urbanization pressure. For instance, an urbanization far beyond the estimations was experienced in a short span of time of 10 years in Yenidogan between 1990 and 2000, and a single parcel of 441 ha was urbanized by being divided into 6.456 parcels. This rapid urbanization in Yenidogan was not seen in Pasakoy, its proximity to the watershed and forest areas has ensured the protection of this area and has maintained its rural character until today. Therefore, Pasakoy and the surrounding lands are one of the most important areas in the district because of its unique structure mentioned. The fact that the $3^{\text {rd }}$ Bridge's road routes pass through there gives rise to the thought that a rapid urbanization process can be initiated like in Yenidogan. The land cover predictions produced for the years 2050 and 2070 and it is envisaged that there will be intensive construction in this region (Figure 4).

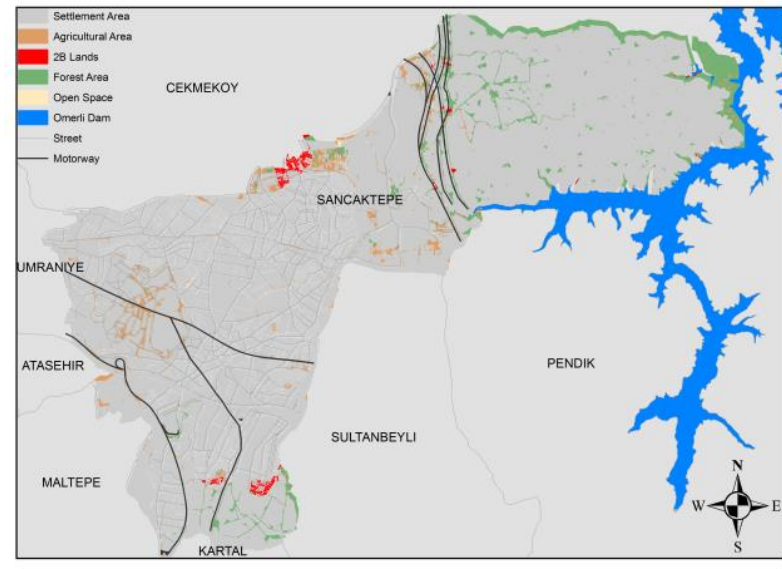

Figure 4. Land cover of Sancaktepe for the year 2070

The simulation models exhibit an estimate consistent with the development trends, and urban housing appears above the expectations for 2070. It is understood from this simulation that the 3rd Bridge's road routes passing through Sancaktepe District will directly affect the urban development if necessary precautions are not taken.

According to the growth coefficients that were calculated as a result of calibration, the growth characteristic in Sancaktepe District breeds in different places and continues by spreading. It is interpreted that the topographic structure of the district has a scarcely any effect on urbanization due to the low slope coefficient. Besides, the fact that urbanization is seen even in places where the slope is greater than 50\% in Safa, Mevlana and Yunus Emre quarters (Figure 4) supports the interpretation made.

It is expected that $83 \%$ of the agricultural areas and $88 \%$ of the forests will be transformed into the settlement areas within a period of over 100 years. Due to the lack of $2 \mathrm{~B}$ lands in the region in 1961, the transformation from these lands into settlement areas could not be determined between 1961 and 2014. However, a transformation of 58\% from 2B lands from 2014 to 2070 indicates that the destruction in forest areas will continue starting from the near future. In the interviews performed with the local people during the field studies conducted in 2015, it was verbally reported to us that the forested lands around Omerli Dam attracted the attention of political powers and investment groups. Although it is not possible to verify this statement with the available data, the fact that the ratio of transforming from $2 \mathrm{~B}$ lands into settlement areas from 2030 is calculated as $58 \%$ confirms these claims (Tables 4 and 5).

The land cover data were produced from cadastral data within the scope of the project. Thus, the reliability of the produced data has been ensured by the state. In addition, the institution cadastre was initiated in the 1920s in Turkey. Thus, it is possible to analyse land cover changes starting from the earlier ones. However, GDLRC has an important responsibility concerning the issue for data reliability and the accuracy of historical data to meet today's requirements. If GDLRC takes on responsibility for this issue, produces land cover from cadastral data and prepares projects to initiate historical cadastral studies that are defined as four-dimensional cadaster, it will create a new resource for its own revolving funds and also will reduce the external dependency of the relevant institutions, organizations and researchers in studies to be carried out on the subject. The UGSM produced within the scope of the project was produced within this scope, and promising results were obtained.

\section{ACKNOWLEDGMENT}

This study was supported by TUBITAK project number $112 \mathrm{~K} 469$ and CUBAP project number M-664.

\section{REFERENCES}

Akın, A., Clarke, K. C., \& Berberoglu, S. (2014). The impact of historical exclusion on the calibration of the SLEUTH urban growth model. International Journal of Applied Earth Observation and Geoinformation 27, Part B(0), 156-168.

Ayazli, I. E. (2011). Simulation model of the urban spread with the effect of transportation networks: Example of the 3rd Bosphorus Bridge, PhD Thesis. Istanbul: YTU, Graduate School of Natural and Applied Sciences.

Ayazli, I. E., Baslik, S., Gultekin, M., Kilic, F., Kuruc, T., Ungan, T., Caliskan, B. (2014). Investigation of the Relationship between Property Pattern and Urban Growth. 5. Remote Sensing and GIS Symposium (UZAL-CBS 2014). Istanbul.

Ayazli, I. E., Kilic, F., Lauf, S., Demir, H., Kleinschmit, B. (2015). Simulating urban growth driven by transportation networks: a case study of the Istanbul Third Bridge. Land Use Policy, 49, 332-340.

Baslik, S. (2008). Dynamic Urban Growth Model: Logistic Regression and Cellular Automata (Istanbul and Lisbon Examples), PhD Thesis. Istanbul: MSGSU Graduate School of Natural and Applied Sciences.

Batty, M. (2007). Cities and Complexity. Cambridge London: MIT Press.

Batty, M., Longley, P. (1994). Fractal Cities A Geometry of Form and Function. Academic Press Limited. 
Benenson, I., Torrens, P. M. (2004). Geosimulation. Automatabased modeling of urban phenomena. Chichester: John Wiley \& Sons Ltd.

Cheng, J. (2003). Modelling spatial \& temporal urban growth, $\mathrm{Ph} . \mathrm{D}$. thesis. Utrecht University.

Clarke, K., Hoppen, S., Gaydos, L. (1997). A Self-Modifying Cellular Automaton Model of Historical Urbanization in the San Francisco Bay Area. Environment and Planning B: Planning and Design, 24, 247-261.

Dietzel, C., Clarke, K. (2007). Toward Optimal Calibration of the SLEUTH Land Use Change Model . Transactions in GIS, 11(1), 29-45.

Hammam, Y., Moore, A., Whigham, P., \& Freeman, C. (2004). Irregular vector-agent based simulation for land-use modelling. Dunedin, New Zealand: SIRC 2004 - The 16th Annual Colloquium of the Spatial Information Research Centre University of Otago.

Jantz, C. A., Goetz, S. J. (2005). Analysis of scale dependencies in an urban land-use-change model. International Journal of Geographical Information Science, 19(2), 217-241. doi:10.1080/13658810410001713425.

Oguz, H., Klein, A. G., Srinivasan, R. (2007). Using the SLEUTH Urban Growth Model to Simulate the Impacts of Future Policy Scenarios on Urban Land Use in the HoustonGalveston-Brazoria CMSA. Research Journal of Social Sciences, 2, 72-82.

Sevik, O. (2006). Application of SLEUTH model in Antalya. Ankara: Master of Science thesis, Middle East Technical University.

Silva, E. A., Clarke, K. C. (2002). Calibration of the SLEUTH urban growth model for Lisbon and Porto, Portugal. Computers, Environment and Urban Systems, 26(6), 525-552.

SLEUTH. (2016). SLEUTH. July 1, 2016

http://www.ncgia.ucsb.edu/projects/gig/About/dtInput.htm.

GDLRC. (2012, 12 11). GDLRC Web Page. Circular No. 1737: received from http://www.tkgm.gov.tr/tr/mevzuat

TSI. (2016). Turkish Statistical Institute.

https://biruni.tuik.gov.tr/medas/?kn=95\&locale=tr on July 11, 2016 